\title{
Intraspecific food resource partitioning in Brazilian silverside Atherinella brasiliensis (Atheriniformes: Atherinopsidae) in a tropical estuary, Brazil
}

\author{
Gitá J. S. Brito, Lidiane G. de Lima, Ronnie E. M. C. C. Oliveira and André Pessanha
}

We investigated the intraspecific partitioning of food resources of the Brazilian silverside Atherinella brasiliensis in a tropical estuary. A total of 1,099 stomachs were analyzed, and the diet consisted mainly of Gastropoda, Ceratopogonidae larvae, Decapoda larvae, Calanoida, Cyclopoida, Hymenoptera and Brachyura. Ordination of the mean volumetric percentage contribution of preys indicated differences in the dietary compositions between sites and size classes. By SIMPER analysis, we detected high dissimilarity between size classes, suggesting ontogenetic niche shifts: the diet of the early juveniles was based in zooplankton, whereas adults consumed mainly benthic macroinvertebrates. These shifts were related to changes in feeding structures and foraging abilities that show a strong relationship with body size, and showed functional trade-offs in swimming capacity, and feeding strategies used to capture prey. Differences in the diet between size classes and habitat selection by Brazilian silverside are likely strategies to avoid intraspecific competition, clearly related to the abundance and accessibility of resources along the estuarine habitats.

Keywords: Coastal areas, Habitat heterogeneity, Trophic strategies.

Nós investigamos a partição intraespecífica de recursos alimentares do peixe-rei Atherinella brasiliensis em um estuário tropical. Um total de 1.099 estômagos foi analisado, e a dieta foi constituída principalmente de Gastropoda, Larva de Ceratopogonidae, Larva de Decapoda, Calanoida, Cyclopoida, Hymenoptera e Brachyura. A análise de ordenação da contribuição do volume das presas indicou diferenças na composição da dieta entre locais e classes de tamanho. Pela análise do SIMPER, nós detectamos alta dissimilaridade entre as classes de tamanho, sugerindo mudanças ontogenéticas: a dieta dos indivíduos menores foi baseada em zooplâncton, enquanto os maiores indivíduos consumiram principalmente macroinvertebrados bentônicos. Essas variações foram relacionadas com mudanças nas estruturas para captura do alimento e na habilidade de forrageamento que evidenciaram uma forte relação com o tamanho do corpo, e mostraram trade-offs funcionais na capacidade de natação e no modo de captura das presas. Diferenças na dieta entre as classes e a seleção de habitat pelo peixe-rei são estratégias para evitar a competição intraespecífica, claramente relacionada com a abundância e a acessibilidade dos recursos alimentares ao longo dos habitats estuarinos.

Palavras-chave: Áreas costeiras, Estratégia Trófica, Heterogeneidade de habitat.

\section{Introduction}

The niche concept proposes that interactions between resources and consumers depend, in part, on how resources affect fitness components of consumers (Leibold, 1995). Indeed, most direct effects of intraspecific food competition in fishes result in changes in population density, survival, and growth (Alanärä et al., 2001). Given such circumstances, understanding how mechanisms contribute to intraspecific partitioning has been a focus of ecological research. Thus, the estuarine fishes are excellent models because they can reduce the impact of competition by partitioning the resources along three main dimensions: habitat, trophic, and temporal segregation (Ross, 1986). Study of the ontogenetic variations in fish diets has also enhanced our ability to understand coexistence strategies in an environment characterized by high amounts of microhabitats, such as estuaries (França et al., 2012).

Estuarine fishes exploit a wide range of prey types, which are locally abundant in the environment, and this has frequently been used to infer trophic plasticity (Hostim-Silva et al., 1995). Several studies of feeding habits in tropical estuarine fishes have reported shifts in prey consumption during the ontogeny (Pessanha, Araújo, 2001), which has

Laboratório de Ecologia de Peixes, Departamento de Biologia, Universidade Estadual da Paraíba, Bodocongó, 58429-500 Campina Grande, PB, Brazil. (GJSB) soteroruda@gmail.com, Dhttps://orcid.org/0000-0001-6713-3770; (LGL) lidianelimauepb@gmail.com, (Dhttps://orcid.org/0000-0002-2636-0739; (REMCCO) ronnie.enderson@gmail.com, Dhttps://orcid.org/0000-0002-1994-6184; (AP) andrepessanhauepb@gmail.com, Dhttps://orcid.org/0000-0003-1878-6251 (corresponding author) 
been associated with the optimal foraging theory proposed by MacArthur, Pianka (1966). However, differences in the physiological abilities, with reference to swimming ability and mouth and jaw size, also result in an expansion in the niche width by differences in predation ability and food requirements to be exploited as fish grow (Ward et al., 2006). Analogous changes are documented in neotropical silversides (Atherinopsidae), including features of gut structure and function (Logothetis et al., 2001; Horn et al., 2006), trade-offs between energy allocation in maintenance and somatic and reproductive growth (Billerbeck et al., 2001; Chizinski et al., 2007), trophic ecomorphology (Cassemiro et al., 2003; Ross et al., 2006) and the relation between fish size and feeding selectivity (Unger, Lewis, 1983, 1991).

The Brazilian Silverside, Atherinella brasiliensis (Quoy \& Gaimard, 1854), is a common estuarine resident and generalist species and is abundant in estuaries (Neves et al., 2006; Alves et al., 2016) and others nearshore shallow water ecosystems, as such beaches (Chagas, Junior, 2013; Lacerda et al., 2014; Favero, Dias, 2015), coastal lagoons (Andreata, 2012) and bays (Paiva Filho, Gianinni, 1990; Pessanha, Araújo, 2001; Carvalho, Spach, 2015). Furthermore, A. brasiliensis, show its important in a key structuring role in estuarine food webs (Campos et al., 2015; Figueiredo, Pessanha, 2016), because generalist species are able to feeding and exploit quantitatively on prey from multiple basal nutrient sources (Claudino et al., 2015). Generally, zooplankton, insects, diatoms form the principal diet of Brazilian silversides in estuaries (Contente $e t$ al., 2011; Alves et al., 2016).

Here we aimed to (1) provide a detailed description of the diet and (2) identify potential competition for food resources between size classes of this species and (3) to relate the morphological traits to the use of resources, identifying potential prey/ fish morphology relationships. We discuss how differences in habitats preferences and foraging strategies among body sizes are major means by which $A$. brasiliensis avoid direct overlap in resource use in a tropical estuary, and morphological traits which are decisive in this strategy.

\section{Material and Methods}

Study area. The Mamanguape River estuary is located on the north coast of the Brazil and is part of the Environmental Protection Area of Barra de Mamanguape (Fig. 1). The regional climate is classified by Köppen as As-type (hot and humid). The mean rainfall recorded in the area is between 1,750 and 2,000 $\mathrm{mm}$ annually, and the mean temperature is approximately $24-26^{\circ} \mathrm{C}$. There is a well-preserved forest mangrove in the area, which grows around the primary channel and tidal creek and extends to $600 \mathrm{ha}$, in addition to Atlantic Forest remnants (Rocha et al., 2008). Endangered species, such as the seahorse, Hippocampus reidi, and the West Indian manatee, Trichechus manatus, are also found in this estuary (Mourão, Nordi, 2003).

Three sampling sites were established along an estuarine salinity gradient and distinct physiographic features (Fig. 1): (1) Mudflat: unvegetated tidal bottoms and found in protected estuaries characterized by lower influence of waves, fine sediment (somewhat muddy), and that during low tide extend $1.22 \mathrm{~km}$, (2) Tidal Creek 1: is a mangrove channel wide and shallow $(0.72 \mathrm{~m})$, which is bordered by a mangrove forest $(5.3 \mathrm{~km})$, substrate is a sandy type that forms sandbars exposed during the low tide, (3) Tidal Creek 2: is a mangrove canal located in the most central part of the estuary, bordered along its entire extension $(1.4 \mathrm{~km})$ of mangrove, deeper $(0.82$ $\mathrm{m})$ and muddy sediment. This research was conducted under SISBIO Collection of Species Permit number 24557-1 issued by ICMBio, Brazilian Environmental Agency.

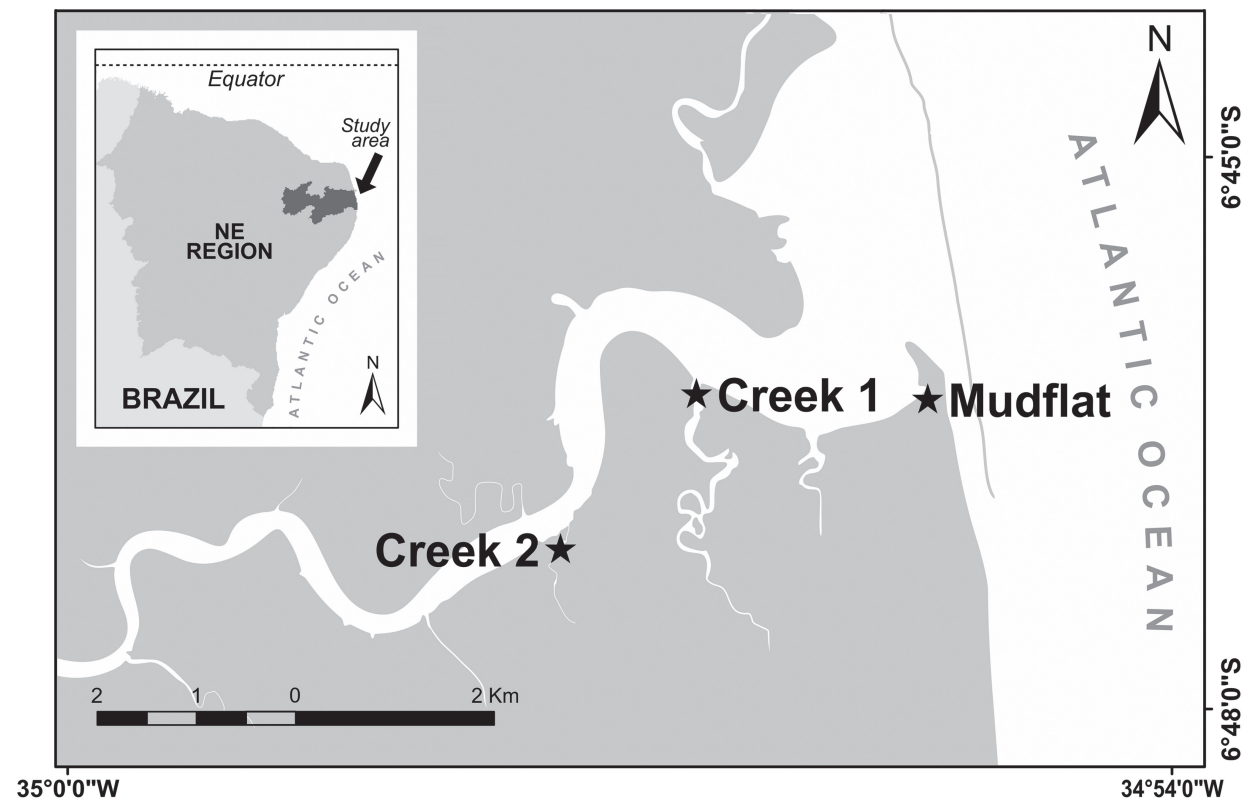

Fig. 1. Study area. Map of the study area with locations of the sampling sites in the Mamanguape River Estuary, Brazil: Mud flat; Tidal Creek 1 and Tidal Creek 2. 
Sampling and data analysis. In order to have a more representative survey of the ichthyofauna, samplings were carried out during both the wet season (February to July 2011) and the dry season (August/2011 to January/2012). The fish were sampled using a beach seine $(10.0 \times 1.5 \mathrm{~m}$; 8 -mm mesh size). The seine hauls were $30-\mathrm{m}$ long, parallel to and close to the shore, and were taken out to a depth of approximately $1.5 \mathrm{~m}$. Each haul covered an area of approximately $30 \mathrm{~m}^{2}$. This procedure was replicated three times in each sampling occasion. The fish collected were later identified, measured (total length in $\mathrm{mm}$ ), and weighed (g). Euthanasia was performed by immersion of fishes in a Eugenol solution (300 mg L-1). After death, we fixed the fishes in $10 \%$ formalin for 15 days and then we moved them to $70 \%$ alcohol. Temperature, salinity and transparency were measured, using a thermometer, an optical refractometer and Secchi disc, respectively.

To investigate the distribution of size classes of $A$. brasiliensis in estuary, the aptured specimens were defined according to Jensen (1997). The individuals were divided into the following size classes: early juveniles $\left(\mathrm{TL}_{1}=<50\right.$ $\mathrm{mm})$, juveniles $\left(\mathrm{TL}_{2}=51-80 \mathrm{~mm}\right)$ and adults $\left(\mathrm{TL}_{3}=>80\right.$ $\mathrm{mm}$ ); the fishes were defined as juveniles if they were less than $1 / 3$ rd asymptotic length, and adults were determined to be approximately $2 / 3 \mathrm{rd}$ of the asymptotic length (JaxiomHarm et al., 2012). The maximum length was obtained from FishBase (http://www.fishbase.org/search.php). This method was applied with the aim of standardize the size of classes up to have a better comparison between them. Voucher specimens (LEP 098) were deposited into the ichthyological collection of the Laboratório de Ecologia de Peixes of the Universidade Estadual da Paraíba (LEP-UEPB).

Permutational analysis of variance (PERMANOVA) was used to determine any significant differences in fish density and biomass and other environmental variables for the different habitats and sampling periods (Anderson et al., 2008). Two fixed factors were selected: habitat (three levels: Mudflat, Creek 1 and Creek 2) and season (two levels: dry and wet). Prior to the analyses, the environmental data were log transformed using $\log _{10}(\mathrm{x}+1)$. The data collected for density and biomass were square-root transformed. Euclidean distance matrices were calculated for the univariate variables.

To analyse each diet, the frequency of occurrence $(\% \mathrm{~F})$, the percentage number $(\% \mathrm{~N})$ and the volume $(\% \mathrm{~V})$ of different food items were calculated (Hyslop, 1980), and the Index of Relative Importance (IRI) was subsequently applied for the quantitative analysis of the stomach contents (Pinkas et al., 1970). Each dietary item was identified to the lowest possible taxon. Although the volumes of unidentifiable materials were also calculated, these were not considered valid dietary categories and were not, therefore, included in a subsequent dietary analysis. For food items that could not be counted, a value of 0.1 was given for their number $(\% \mathrm{~N})$ when they were present in the diet to offset distortions in the index (Abdurahiman et al., 2010).
The PCO (Principal Coordinates) ordination was applied to obtain a graphical representation of the size classes, using the volume values. A matrix of food items was constructed to reduce the number of samples to facilitate the detection of feeding patterns, as described by Schafer et al. (2002) and Platell, Potter (2001). This means that the dietary data for a single individual contained large numbers of zero values, giving rise to instabilities in the calculation of similarities at an individual level, which greatly reduced the effectiveness of multivariate analyses of dietary data. This problem was efficiently minimised by averaging the dietary data $(\% \mathrm{~V})$ for pooling stomachs contents of 3 to 5 individuals to produce a new series of replicates for a given factor (i.e. size classes or season).This ordinations were performed on Bray-Curtis similarity matrices to determine the extent to which individual factors influenced the dietary composition. Similarity percentage analysis (SIMPER) was used to determine which items were most responsible for the Bray-Curtis similarity within groups. The multivariate analyses were performed with the PRIMER software package, version 6.0 (Clarke, 1993).

Feeding strategies was analyzed following the graphical method of Costello (1990), modified by Amundsen et al. (1996). In this method, the prey-specific $(\% \mathrm{~V})$, defined as the average volumetric contribution of a food item (only for individuals that had this food item in their stomach), was plotted against the frequency of occurrence $(\% \mathrm{FO})$, and then interpreted with respect to the position within the graph. The position of the food items in the diagram represents the feeding strategy of the predator in terms of specialization or generalization. The Shannon-Wiener diversity index (Krebs, 1989), which corresponds to dietary breadth, was used for each species using a volumetric data of feeding.

Functional traits. Sixteen morphological variables were measured based on Keast, Webb (1966), Gatz Jr (1979), Watson, Balon (1984), and Beaumord, Petrere Jr. (1994). A numeric vernier calliper $(0.1 \mathrm{~mm}$ precision $)$ was used to measure: total length (TL), standard length (SL), body height (BH), mean body height (MHB), body width (BW), head length (HL), head height $(\mathrm{HH})$, relative eye height (ERH), pectoral fin length (PFL), pectoral fin width (PFW), caudal fin height $(\mathrm{CFH})$, caudal peduncle length (CPL), caudal peduncle height $(\mathrm{CPH})$, caudal peduncle width (CPW), mouth width (WM) and mouth height (HM). Morphological measurements were transformed following the method of Schaefer (1992) and Pessanha et al. (2015). Such transformations allow the removal of the body size effect, which standardises the measures, taking into account the effect of standard length on the analyzed morphological attributes. Morphological variations were examined using principal component analysis (PCA). PCA was performed on the mean values of 9 functional traits calculated for the fish species studied to evaluate the morphological affinities of each age classes. 


\section{Results}

Environmental variables. Environmental data showed differences between sites and season (PERMANOVA, $\mathrm{P}<$ 0.001) (Tab. 1). There were no differences in temperature among sites and seasons. Salinity and transparency were different between sites and seasons (PERMANOVA, $\mathrm{P}<$ $0.001)$. Only transparency showed interactions between sites and seasons (PERMANOVA, $\mathrm{P}<0.001$ ). The highest salinity and water transparency were recorded in Mudflat and Tidal Creek 1, and the highest values were recorded during the dry season.

Tab. 1. Environmental parameters are displayed as mean $\pm \mathrm{SE}$ (Standart error). Levels of significance for differences for sites (Mudflat, Tidal Creek 1 and Tidal Creek 2) and Seasons (Wet and Dry) in Mamanguape River estuary, Brazil.

\begin{tabular}{lcccccccccc}
\hline & \multicolumn{2}{c}{ Mudflat } & \multicolumn{2}{c}{ Tidal Creek1 } & \multicolumn{2}{c}{ Tidal Creek2 } & \multicolumn{2}{c}{ Sites } & \multicolumn{2}{c}{ Season } \\
\cline { 2 - 9 } & Wet & Dry & Wet & Dry & Wet & Dry & Pseudo -F & P & Pseudo -F & P \\
\hline Temperature & $29.0 \pm 0.3$ & $29.6 \pm 0.3$ & $30.0 \pm 0.3$ & $29.3 \pm 0.6$ & $29.9 \pm 0.6$ & $28.9 \pm 0.5$ & 0.440 & 0.6521 & 1.387 & 0.2414 \\
Salinity & $24.4 \pm 1.3$ & $34.9 \pm 0.6$ & $26.8 \pm 1.5$ & $31.3 \pm 1.3$ & $17.2 \pm 2.0$ & $16.9 \pm 1.5$ & 19.465 & 0.0001 & 8.298 & 0.0003 \\
Transparency & $37.1 \pm 2.6$ & $44.6 \pm 3.0$ & $50.6 \pm 2.3$ & $56.6 \pm 1.6$ & $33.3 \pm 3.9$ & $46.0 \pm 3.4$ & 10.798 & 0.0002 & 16.485 & 0.0002 \\
\hline
\end{tabular}

Distribution and abundance. During the study, the highest abundance and biomass were found in sites situated at the entrance of the estuary (Mudflat and Tidal Creek 1), and PERMANOVA $(\mathrm{P}<0.001)$ indicated significantly spatial differences (Fig. 2). However, temporally, these descriptors were not significantly different between hydrologic seasons.
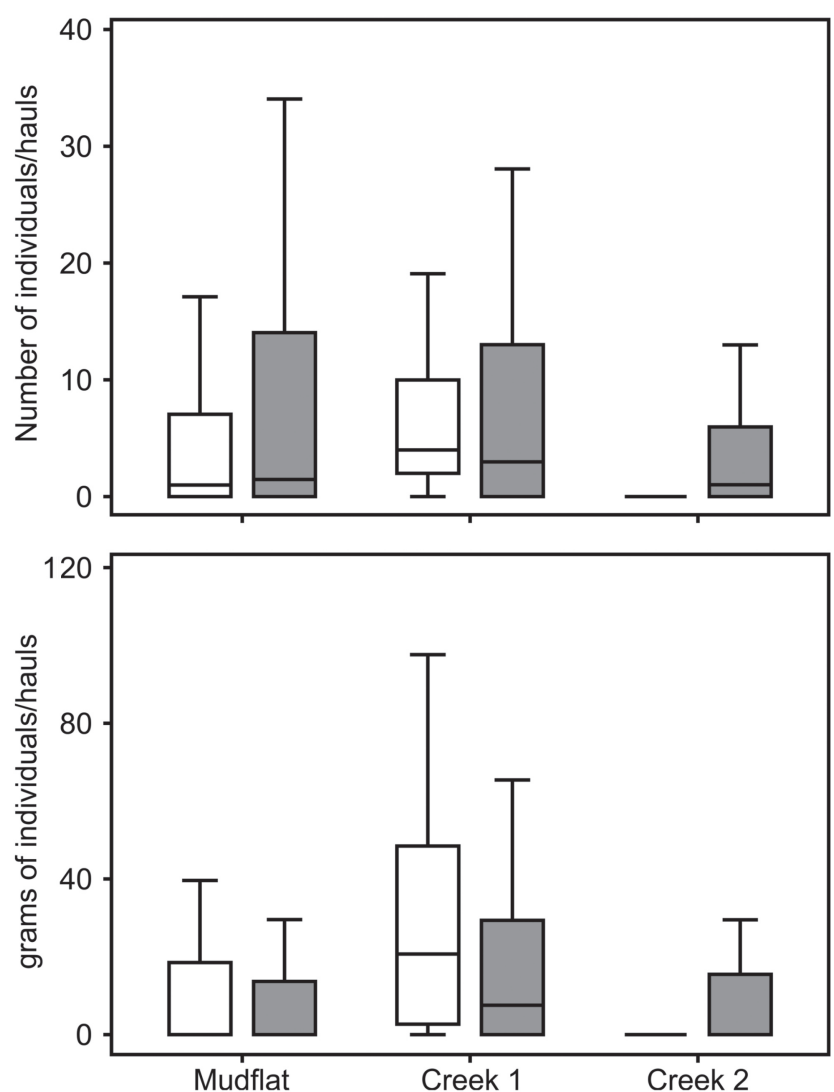

Fig. 2. Box-plot of spatial and temporal variation of number of individuals (CPUE average $\pm \mathrm{SE}$ ) and Biomass $( \pm \mathrm{SE})$ of $A$. brasiliensis collected Mamanguape river estuary in Brazil. Bold lines indicate medians, hinges indicate the $25^{\text {th }}$ and $75^{\text {th }}$ percentiles, whiskers indicate the largest and smallest observation within a distance of 1.5 the box size. White bar= Wet season and Dark Gray bar= Dry season.
All individuals caught had a total length (TL) of between 16-130 mm (Fig. 3). The age structure of A. brasiliensis differed among sites. The smallest individuals (small juveniles) showed the highest frequency (46\%) in Mudflat, whereas the largest individuals (adults) were mostly in Tidal Creek 2.

Spatial, temporal and ontogenetic shift on diet. We analyzed a total of 1099 stomachs, of which 259 were empty $(23.6 \%)$. The overall diet composition was dominated by Infauna, zooplankton and insect preys (IRI $=74.7 \%, 20 \%$ and $3.8 \%$, respectively). The diet of $A$. brasiliensis consisted mainly of Gastropoda (IRI $=60.3 \%)$, Ceratopogonidae larvae (9.5\%), Decapoda larvae (7.6\%), Calanoida (7.4\%), Cyclopoida (3.5\%), Hymenoptera (2.8\%), and Brachyura $(2.7 \%)$.

Significant variations were found in the diet of $A$. brasiliensis between sites (PERMANOVA: $\mathrm{F}_{2,220}=16.57$; $\mathrm{P}<0.001$ ) and size classes (PERMANOVA: $\mathrm{F}_{2,220}=8.92$; $\mathrm{P}<0.001$ ), but not hydrological periods (PERMANOVA: $\left.\mathrm{F}_{2,220}=0.99 ; \mathrm{P}=0.61\right)$. We detected considerable spatial variation in the main prey items among sites (Fig. 4). For instance, in Mudflat caught fish had more Gastropoda and Ceratopogonidae larvae in their stomachs, whereas Calanoida, Cyclopoida, and Decapoda larvae were abundant at Tidal Creek 1, and Hymenoptera and Polychaeta dominated at Tidal Creek 2 (Fig. 4). Our data suggest ontogenetic changes in dietary compositions at each site, with reduced contributions made by zooplankton items (Calanoida, Cyclopoida and Decapoda Larvae) for the early juveniles( $\left.\mathrm{TL}_{1}\right)$, whereas the importance of benthonic organisms (Polychaeta, Brachyura, Ceratopogonidae larvae and Gastropoda) tended to increase in larger individuals $\left(\mathrm{TL}_{3}\right)$ (Fig. 4).

By principal coordinates analysis (PCoA) we identified spatial and ontogenetic patterns within the dietary samples of A. brasiliensis (Fig. 5). The Mudflat samples lay to the lower part of the diagram due to the similarity of the diets, whereas samples from Tidal Creek 1 and 2 lay to the upper part of the diagram. By SIMPER analysis, we detected high 
dissimilarity and identified those items that most contributed to the $A$. brasiliensis diet for each site and age class. Gastropoda, Ceratopogonidae and Calanoida (Mudflat), Decapoda larvae (Creek 2) and Hymenoptera (Creek 3) made the greatest contributions to the dissimilarity between sites.
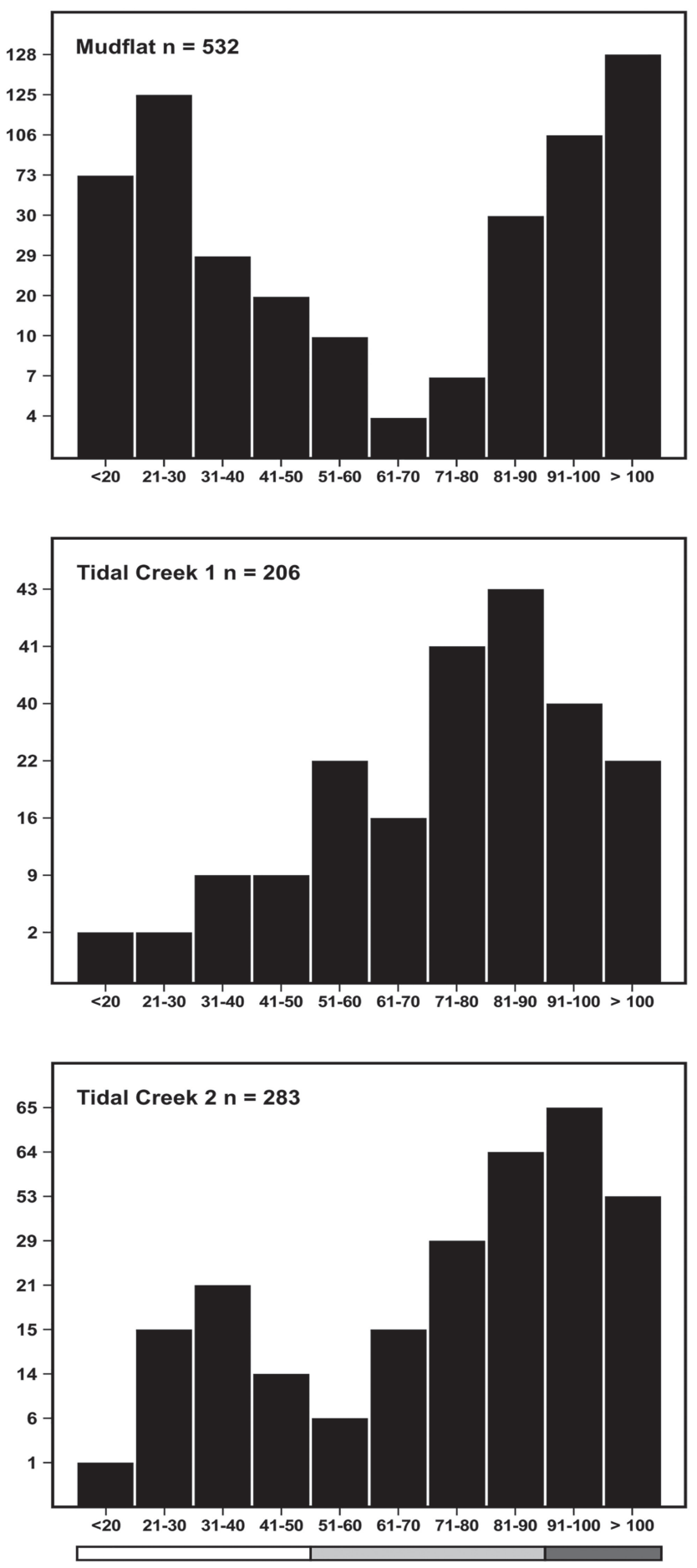

Fig. 3. Size distributions of Atherinella brasiliensis at sampling areas (Mudflat, Tidal Creek 1 and Tidal Creek 2) in de Mamanguape estuary river. Number of individuals (n) is listed. Age Class: White bar= small juveniles; Light Gray bar= juveniles, and Dark Gray bar= adults.

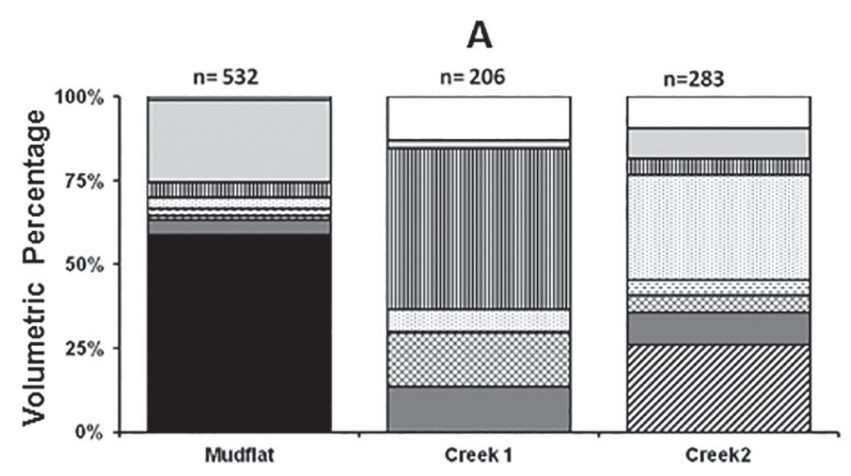

B
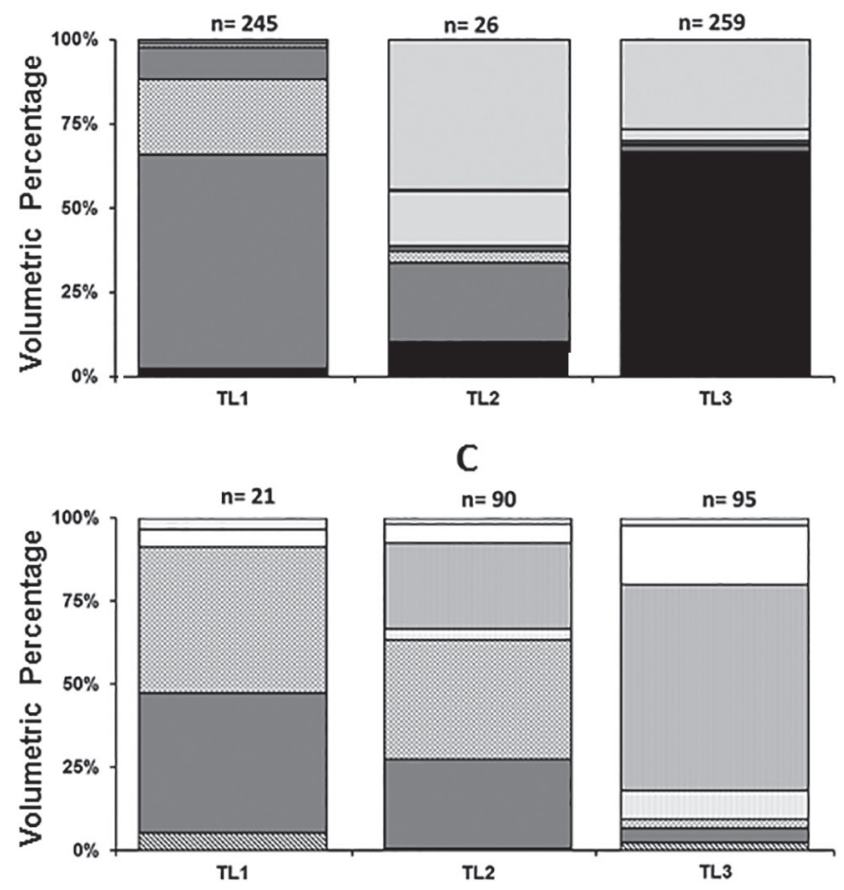

D

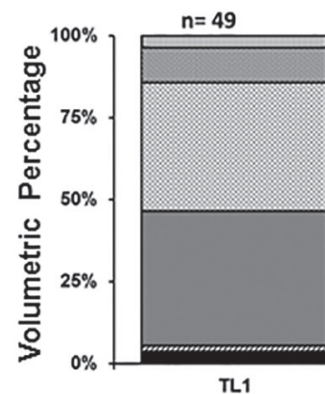

$n=63$

$\mathrm{n}=171$
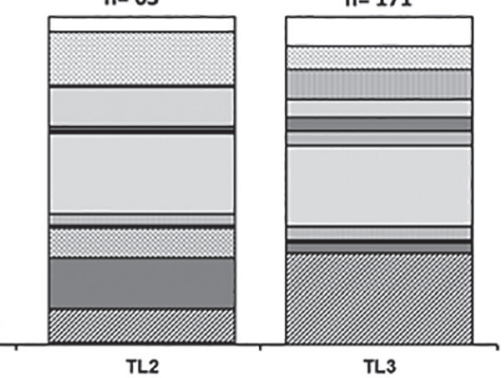

TL3

- GASTROPODA ECYCLOPOIDA

口HYMNOPTERA 口CERATOPOGONIDAE

๑POLYCHAETA 口CALANOIDA ๑FORAMINIFERA ФDECAPODALARVAE EINSECTA ni ๑COLEOPTERA 口BRACHYURA

Fig. 4. Volumetric Percentage $(\% \mathrm{~V})$ per habitat (a) of the most important food items in the diet each size classes $\left(\mathrm{TL}_{1}=\right.$ small juveniles; $\mathrm{TL}_{2}=$ juveniles and $\mathrm{TL}_{3}=$ adults) of the Mamanguape river estuary, northeastern Brazil. (b: Mudflat, c: Tidal Creek 1 and d: Tidal Creek 2). 
In relation to size classes, the smallest and largest individuals of $A$. brasiliensis formed groups in the lower part of the diagram, whereas the intermediate sized fish formed a very broad group in the upper diagram (Fig. 5). By SIMPER analysis, we detected greater volumes of zooplankton items (Calanoida and Cyclopoida) in the diet of the smallest individuals $\left(\mathrm{TL}_{1}\right)$, whereas Gastropoda and Ceratopogonidae were more important in the diets of largest individuals $\left(\mathrm{TL}_{3}\right)$, and Hymenoptera and Calanoida were important items to intermediate sized fish $\left(\mathrm{TL}_{2}\right)$.
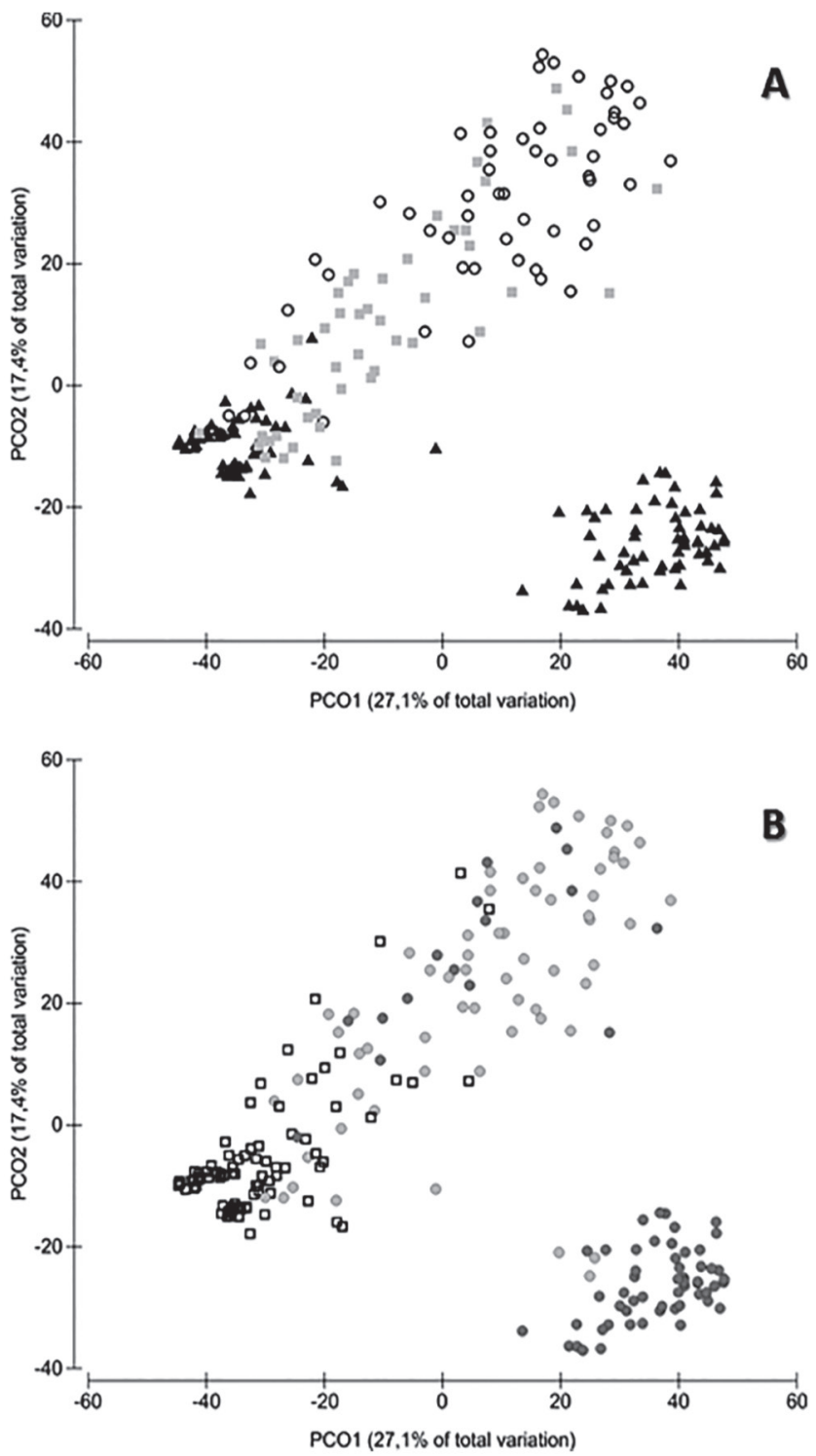

Fig. 5. Principal coordinate analysis ordination (PCO) coded by habitat (a) and size classes (b) for Atherinella brasiliensis in the Mamanguape River estuary, Brazil. Symbols Habitat: Mud flat (Full Black Triangle); Tidal Creek 1 (Gray Square); Tidal Creek 2 (Black Circle); Symbols size classes: Small juveniles (Open Black Square); Juveniles (Light Gray Circle) and Adults (Dark Gray Circle).
Functional traits. When combined, the Principal Components 1 and 2 (PC1 and PC2) explained 38.7\% of the variation in variation in functional traits; $\mathrm{PC} 1$ explained $21.4 \%$ and PC2 explained $17.3 \%$ (Tab. 2) The high scores of PC1 were associated with RMW, RHL, and CPCI, whereas low scores were associated with IVF. High scores of PC2 were associated with IVF and RH. The PCA pattern shows that positive scores are associated with the small size class (plotted in the right part of the diagram), whereas adults were correlated with negative scores (plotted in the left part of the diagram) (Fig. 6).

Tab. 2. Factor loads from principal component analysis (PCA) on functional traits of Atherinella brasiliensis in Mamanguape River estuary. Functional traits: $\mathrm{CI}=$ Compression Index; $\mathrm{RH}=$ Relative Height; $\mathrm{RPL}=$ Relative Peduncle Length; $\mathrm{CPCI}=$ Caudal Peduncle Compression Index; IVF= Index of ventral flattening; APRF $=$ Aspect of Pectoral Fin Ratio; RHL= Relative Head Length; RMW= Relative Mouth Width; MAR= Mouth aspect ratio.

\begin{tabular}{lcc}
\hline Factor loads & PC 1 & PC2 \\
\hline CI & 0.14 & 0.10 \\
RH & -0.28 & -0.55 \\
RPL & 0.14 & 0.10 \\
CPCI & 0.43 & 0.33 \\
IVF & 0.01 & -0.61 \\
APFR & 0.23 & 0.05 \\
RHL & 0.43 & -0.23 \\
RMW & 0.57 & -0.24 \\
MAR & -0.36 & 0.28 \\
\hline Eigenvalues & 1.92 & 1.56 \\
Explained Variance (\%) & 21.4 & $17.4 \ldots \ldots \ldots \ldots \ldots \ldots \ldots \ldots \ldots \ldots \ldots \ldots \ldots \ldots \ldots \ldots \ldots \ldots \ldots$ \\
\hline
\end{tabular}

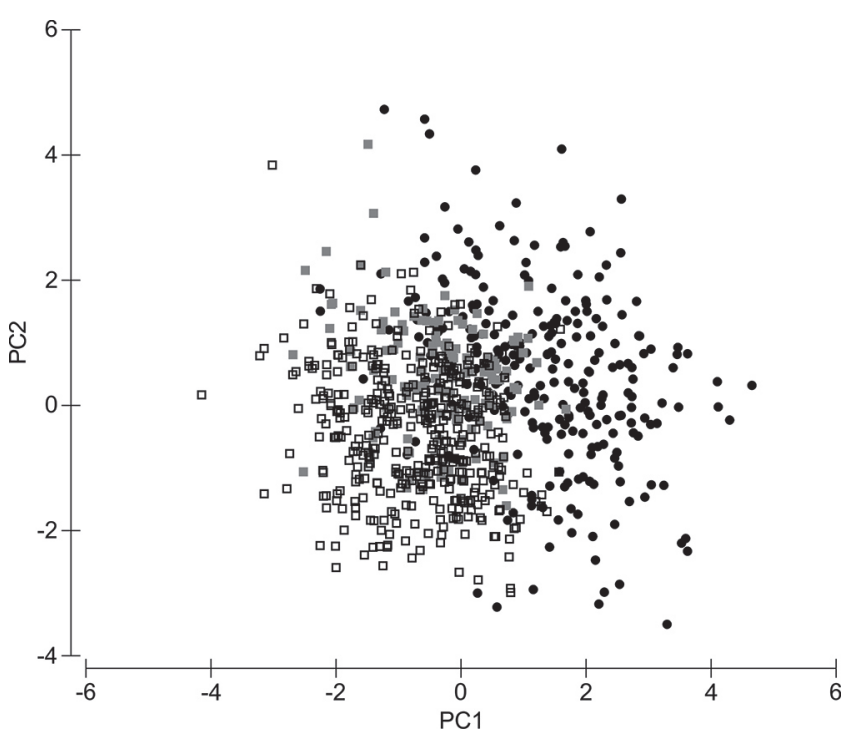

Fig. 6. Ordination diagram from the first two principal components for the functional traits of Atherinella brasiliensis in Mamanguape river estuary. Symbols size classes: Small juveniles (Open Black Square); Juveniles (Gray Circle) and Adults (Black Circle). 
Niche overlap and feeding strategy. Feeding overlap occurred between the first two age classes at Mudflat and Tidal Creek 1 (0.70 and 0.94, respectively), whereas there was consistent overlap between age classes at Tidal Creek 2. In the Amundsen diagram, the results show generalized feeding habits and broad feeding niche; the preys were located in the lower left and bottom parts of the diagram (Fig. 7). Shifts in the main resource amongst the smaller and intermediate age classes (small juveniles and juveniles) were observed, and comprised largely of Calanoida and Cyclopoida. Decapoda larvae and Hymenoptera contributed most to the diets of adults.
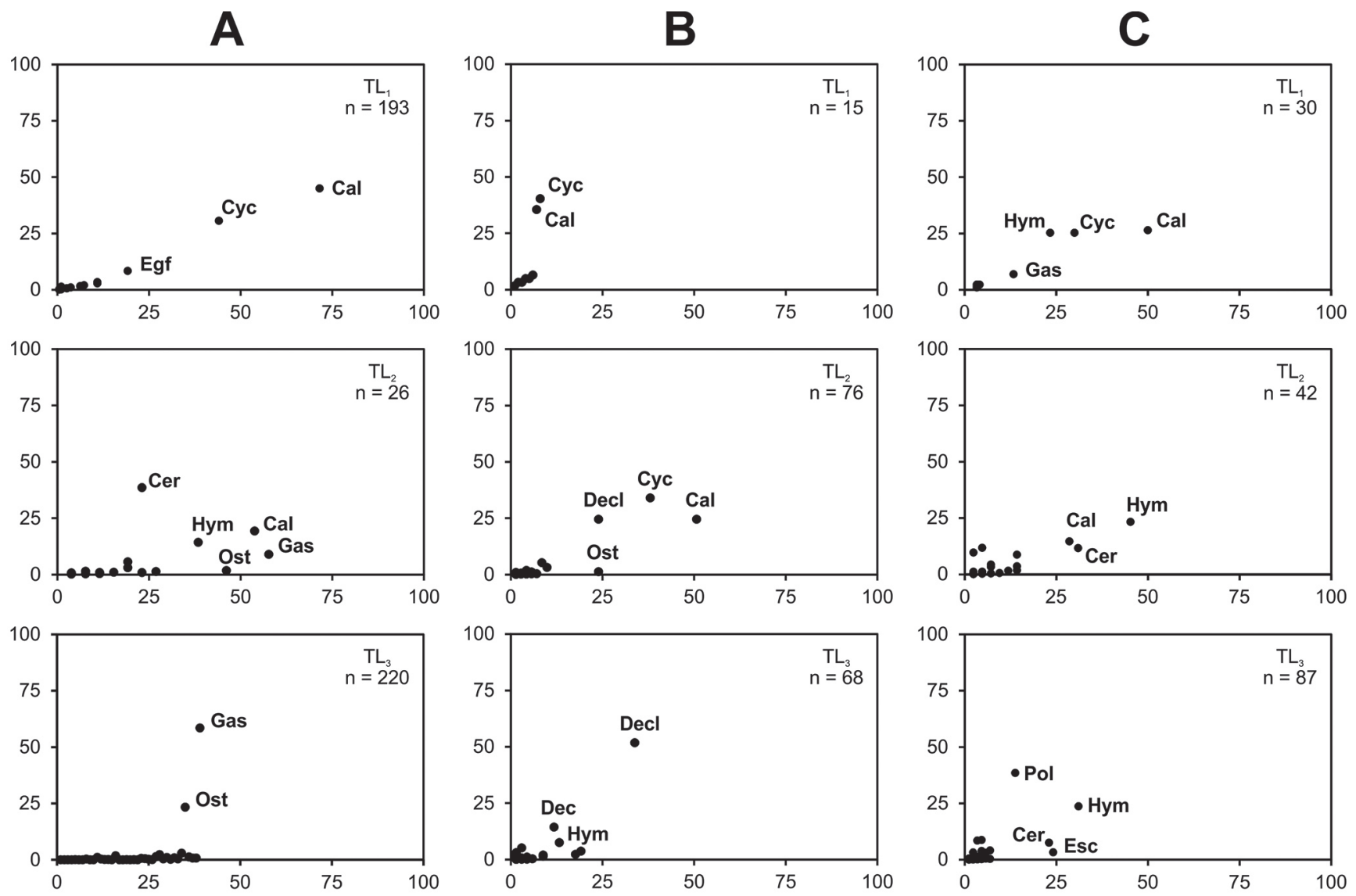

Fig. 7. Feeding strategy for Atherinella brasiliensis in Mamanguape river estuary: $\mathrm{A}=$ Mudflat; $\mathrm{B}=$ Tidal Creek 1 and $\mathrm{C}=$ Tidal Creek 2. Food items: Cyc, Cyclopoida; Cal, Calanoida; Dec, Decapoda; Decl, Decapoda larvae; Hym, Hymnoptera; Egf, Fish eggs; Cer, Ceratopogonidae larvae; Ost, Ostracoda; Gas, Gastropoda; Pol, Polychaeta; Esc, Scale. $\left(\mathrm{TL}_{1}=\mathrm{small}\right.$ juveniles; $\mathrm{TL}_{2}=$ juveniles and $\mathrm{TL}_{3}=$ adult).

\section{Discussion}

Brazilian silversides in the tropical estuary exhibited marked spatial abundance and ontogenetic diet shifts. Overall, A. brasiliensis was abundant and widely distributed throughout the estuary, despite their higher abundance in Mudflat. These results are consistent with the findings of Alves et al. (2016) in this estuary. Three characteristics of $A$. brasiliensis were identified as factors important to its success in estuarine areas: salinity tolerance (SouzaBastos, Freire, 2011), slow rates of growing with positive alometric coeficients and short-lived life cycle (Contente et al., 2011; Carvalho et al., 2017). Furthermore, in accordance with the findings of other authors, the Brazilian silverside showed higher abundance in habitats less affected by the hydrodynamic process, such as extensive sand (Pessanha,
Araujo, 2001) and mud flats (Campos et al., 2015), and also in sites which provide more availability of habitats, as such tidal creeks and mangroves (Neves et al., 2006; Fávaro et al., 2007). As a consequence, these sheltered habitats can be used as refuges from predation and/or contribute significantly to high food resource. Most of the Brazilian silversides used these areas in the Mamanguape estuary as regular nursery habitats. The physiological capacities (Hostim-Silva et al., 1995; Neves et al., 2006) and reproductive strategy (Fávaro et al., 2003) of Brazilian silversides might also influence and drive their success in estuarine areas.

In the present study, higher proportions of adults at creeks and small juveniles at mudflats were identified as a main spatial difference between age classes of A. brasiliensis. These occupations of different habitats support the importance of shifts in niche dimension during the life cycle 
of fishes. Several studies have shown that $A$. brasiliensis changes its habitat use throughout its life stages (Santos et al., 1999; Fávaro et al., 2003; Chagas, Junior, 2013), suggesting that deeper waters are preferred for feeding and initiating gonad maturation, and shallow habitats for depositing eggs when spawning (Cortinhas et al., 2016). These patterns appear to be associated with ecophysiological factors, as described by Sheaves et al. (2014), interpreted as a result of abilities to access and use different nursery areas or use nursery grounds in different ways.

The diet of $A$. brasiliensis was based on zooplankton (Calanoida, Cyclopoida and Decapoda larvae), allochthonous items (Hymenoptera and others insects), and benthic organisms (Gastropoda, Polychaeta and Ceratopogonidae larvae). These results are in agreement with the findings of other authors (Ringuelet, 1942; Paiva, Schefer, 1982; Bemvenuti, 1990; Rodrigues, Bemvenuti, 2001), and most of them show a great contribution of these items as nutritional resources for the fitness of individuals (somatic and reproductive growth) and thus contribute to ecological success of populations. Additionally, zooplankton have a higher energy content, explained by the ability of planktonic invertebrates to store large amounts of lipids (Whitfiled, 1985); benthic invertebrates and insects (by adults) make feeding more energetically attractive to fishes and, thus, results are consistent with optimal foraging theory. However, our results share some dissimilarities with Alves et al. (2016). One reason for this could be that we analyzed the diet of fish caught in the tidal creeks, while those authors only analyzed fish from the main channel of the river Mamanguape.

Our results indicate that $A$. brasiliensis consumes a large variety of prey, reflecting their ability in foraging in diverse habitats. Nevertheless, the same prey categories were consumed at multiple sites. In creeks, zooplankton represented the main diet item but it was consumed less in Tidal Creek 2, followed by insect and Polychaeta, whereas in Mudflat the principal prey item was Gastropoda. According to Figueiredo, Pessanha (2016), the nature of available prey which inhabits these habitats in this estuary depends on the environmental characteristics, such as substrate and salinity gradient. Therefore, our findings reinforce that spatial heterogeneity is an important factor that influence fish feeding habits. With regards to the macrofauna and zooplankton in Mamanguape estuary, some studies have shown a distribution pattern at different spatial scales (Nobrega-Silva et al., 2016; Moura et al., 2016; Linden et al., 2017), which has an important role in this food web (Campos et al., 2015; Claudino et al., 2015; Figueiredo, Pessanha 2016).

Size-related dietary changes also were observed during the study, with indications of ontogenetic niche shifts: the diet of the smallest class was based on zooplankton, whereas larger individuals consumed mainly benthic macroinvertebrates. The PCO analysis reflected these progressive ontogenetic differences, demonstrating that the diet composition changes between age classes. Our results also support previous research regarding the transition from zooplanktivorous to zoobenthivorous, as reported for other atherinopsids (Bemvenuti, 1990; Chizinski et al., 2007; Chagas, Junior, 2013). Second, differences in foraging abilities reflect an increase in the efficiency of handling procedure principally to feed on benthic preys (Polychaeta, Brachyura, and Gastropoda), followed by changes swimming ability to capture of preys (Hourston et al., 2004; Ross, 2006). Contente et al. (2011) provides overviews that body form in Brazilian silversides can influence feeding performance, due to a forked caudal fin which is ideal for maneuverability and mobility in preys capture. Billerbeck et al. (2001), in a study of swimming performance in Menidia menidia (Atlantic silverside), found evidence of trade-offs among locomotor performance and substantial differences in intrinsic growth rates and food consumption. Thus, ontogenetic changes might allow Brazilian silverside to maximize their energy storage in order to grow quickly, making them less vulnerable to predation, which is consistent with our findings.

Our PCA analysis corroborated these shifts, which are principally related to changes in the mouth and head size, thus providing evidence of the importance of intraspecific resource partitioning. Intraspecific variation in consumer body size increases the range of acceptable prey sizes and, thus, can alleviate intraspecific competition (Bolnick et al., 2011). Intraspecific variation in consumer body size increases the range of acceptable prey sizes and, thus, can alleviate intraspecific competition. We found that the smallest juveniles of $A$. brasiliensis were associated with Mouth aspect ratio (MAR) and Relative Height (RH), which have characteristics such as narrow mouths and large aperture, followed by the higher capacity for making vertical turns in the water column, facilitating the capture of small-size prey such as Calanoida and Cyclopoida. Zooplanktivores are filter-feeders that engulf a large amount of water and then collect the small suspended particles (Faye et al., 2012). For adults, wide Relative Head Length (RHL) and Relative Mouth Width (RMW) are also considered indicative of similarity in food acquisition of items that inhabit the substrate, such as Gastropoda and Polychaeta. Segregation by size and habitats among estuarine fishes minimizes intraspecific niche overlap by increased resource partitioning (Schlosser, 1987).

In conclusion, our data support the hypothesis that differences in the diet between size classes and habitat selection by $A$. brasiliensis are strategies for avoiding intraspecific competition, clearly related to abundance and accessibility of resources in the estuary. Furthermore, the generalist and opportunistic feeding strategy of $A$. brasiliensis allow sharing resources through consumption of different amounts of the same prey groups. This often produces asymmetries in consumer-resource dynamics that are driven primarily by population density and, to some extent, by size and age classes, which contribute to the partitioning of resources. 


\section{References}

Abdurahiman KP, Nayak TH, Zacharia PU, Mohamed KS. Trophic organization and predator-prey interactions among commercially exploited demersal finfishes in the coastal waters of southeastern Arabia Sea. Estuar Coast Shelf Sci. 2010; 87(4):601-10.

Alves VEN, Patrício J, Dolbeth M, Pessanha A, Palma ART, Dantas EW, Vendel AL. Do different degrees of human activity affect the diet of Brazilian silverside Atherinella brasiliensis? J Fish Biol. 2016; 89(2):1239-57.

Amundsen P-A, Glaber H-M, Staldvik FJ. A new approach to graphical analysis of feeding strategy from stomach contents data modification of the Costello (1990) method. J Fish Biol. 1996; 48(4):607-14.

Anderson MJ, Gorley RN, Clarke KR. PERMANOVA + for PRIMER: Guide to software and statistical methods. Plymouth: PRIMER-E; 2008.

Andreata JV. Ictiofauna da lagoa Rodrigo de Freitas, estado do Rio de Janeiro: composição e aspectos ecológicos. Oecol Aust. 2012; 16(3):467-500.

Beaumord AC, Petrere Jr M. Fish communities of Manso River, Chapada dos Guimarães, MT, Brazil. Acta Biol Vene. 1994; 152:21-35.

Bemvenuti MA. Hábitos alimentares de peixes-rei (Atherinidae) na região estuarina da lagoa dos Patos, RS, Brasil. Atlântica. 1990; 12(1):79-102.

Billerbeck JM, Lankford Jr TE, Conover DO. Evolution of intrinsic growth and energy acquisition rates. I. Trade-offs with swimming performance in Menidia Menidia. Evolution. 2001; 55(9):1863-72.

Bolnick DI, Marasekare P, Araujo MS, Bürger R, Levine JM, Novak M, Rudolf VHW, Schreiber SJ, Urban MC, Vasseur DA. Why intraspecific trait variation matters in community ecology. Trends Ecol Evol. 2011; 26(4):183-92.

Campos DMAR, Silva AF, Sales NS, Oliveira REMCC, Pessanha ALM. Trophic relationships among fish assemblages in a mudflat within Brazilian marine protected area. Braz J Oceanogr. 2015; 63(2):135-46.

Carvalho BM, Spach HL. Habitat use by Atherinella brasiliensis (Quoy \& Gaimard, 1825) in intertidal zones of a subtropical estuary, Brazil. Acta Sci Biol Sci. 2015; 37(2):177-84.

Carvalho BM, Barradas JRS, Fontoura, NF, Spach, HL. Growth of the silverside Atherinella brasiliensis in a subtropical estuary with some insights concerning the Weight-Length relationship. An Acad Bras Ciênc. 2017; 89(3 Suppl.):2261-72.

Cassemiro FAS, Hahn NS, Rangel TFLVB. Diet and trophic ecomorphology of the silverside, Odontesthes bonariensis, of the Salto Caxias reservoir, rio Iguaçu, Paraná, Brazil. Neotrop Ichthyol. 2003; 1(2):127-31.

Chagas RB, Júnior OMC. Biologia reprodutiva e ecologia trófica de Atherinella brasiliensis (Quoy e Gaimard, 1825, Atherinopsidae) ocorrentes na praia de Botelho, Ilha de Maré, Baía de Todos os Santos-BA, Brasil. Rev Bras Biocienc. 2013; 19(1):46-59.

Chizinski CJ, Huber CG, Longoria M, Pope KL. Intraspecific resource partitioning by an opportunistic strategist, inland silverside Menidia beryllina. J Appl Ichthyol. 2007; 23(2):147-51.

Clarke KR. Non-parametric multivariate analysis of changes in community structure. Aust J Ecol. 1993; 18(1):117-43.
Claudino MC, Pessanha ALM, Araújo FG, Garcia AM. Trophic connectivity and basal food sources sustaining tropical aquatic consumers along a mangrove to ocean gradient. Estuar Coast Shelf Sci. 2015; 167(A):45-55.

Contente RF, Stefanoni MF, Spach HL. Feeding ecology of the Brazilian silverside Atherinella brasiliensis (Atherinopsidae) in a subtropical estuarine ecosystem. J Mar Biol Assoc UK. 2011; 91(6):1197-205.

Cortinhas MCS, Kersanach R, Proietti M, Dumont LFC, D’Incao F, Lacerda ALF, Prata PS, Matoso DA, Noleto RB, Ramsdorf W, Boni TA, Prioli AJ, Cestari MM. Genetic structuring among silverside fish (Atherinella brasiliensis) populations from different Brazilian regions. Estuar Coast Shelf Sci. 2016; 178:148-57.

Costelo MJ. Predator feeding strategy and prey importance: a new graphical analysis. J Fish Biol. 1990; 36(2):261-63.

Fávaro LF, Lopes SCG, Spach HL. Reprodução do peixe-rei, Atherinella brasiliensis (Quoy and Gaimard) (Atheriniformes, Atherinidae), em uma planície de maré adjacente a gamboa do Baguaçu, baía de Paranaguá, Paraná, Brasil. Rev Bras Zool. 2003; 20(3):501-06.

Fávaro, LF, Oliveira EC, Verani NF. Estrutura da população e aspectos reprodutivos do peixe-rei Atherinella brasiliensis (Quoy \& Gaimard) (Atheriniformes, Atherinopsidae) em áreas rasas do complexo estuarino de Paranaguá, Paraná, Brasil. Rev Bras Zool. 2007; 24(4):1150-56.

Favero JM, Dias JF. Juvenile fish use of the shallow zone of beaches of the Cananeia-Iguape coastal system, southeastern Brazil. Braz J Oceanogr. 2015; 63(2):103-14.

Faye D, Le Loc'h F, Thiaw OT, Morais LT. Mechanisms of food partitioning and ecomorphological correlate in ten fish species from a tropical estuarine marine protected area (Bamboung, Senegal, West Africa). Afr J Agric Res. 2012; 7(3):443-55.

Figueiredo GGAA, Pessanha ALM. Comparative study of trophic organization of juvenile fish assemblages of three tidal creeks in a tropical semi-arid estuary. J Fish Biol. 2016; 89(1):680-95.

França S, Vasconcelos RP, Fonseca VF, Tanner SE, ReisSantos P, Costa MJ, Cabral HN. Predicting fish community properties within estuaries: Influence of habitat type and other environmental features. Estuar Coast Shelf Sci. 2012; 107:110.

Gatz Jr AJ. Community organization in fishes as indicate by morphological features. Ecology. 1979; 60(4):711-18.

Horn MH, Gawlicka AK, German DP, Logothetis EA, Cavanagh JW, Boyle KS. Structure and function of the stomachless digestive system in three related species of New World silverside fishes (Atherinopsidae) representing herbivory, omnivory, and carnivory. Mar Biol. 2006; 149:1237-45.

Hostim-Silva M, Clezar L, Ribeiro GC, Machado C. Estrutura populacional de Xenomelaniris brasiliensis (Quoy and Gaimard, 1824) na Lagoa da Conceição, SC. Braz Arch Biol Techn. 1995; 38(3):949-60.

Hourston M, Platell ME, Valesini FJ, Potter IC. Factors influencing the diets of four morphologically divergent fish species in nearshore marine waters. J Mar Biol Assoc UK. 2004; 84(4):805-17.

Hyslop EJ. Stomach contents analysis - a review of methods and their application. J Fish Biol. 1980; 17(4):411-29.

Jaxion-Harm J, Saunders J, Speight MR. Distribuition of fish in seagrass, mangroves and coral reefs: life-stage dependent habitat use in Honduras. Rev Biol Trop. 2012; 60(2):683-98. 
Jensen AL. Origin of the relation between $\mathrm{K}$ and $\mathrm{L}_{\text {inf }}$ and synthesis of relations among life history parameters. Can J Fish Aquat Sci. 1997; 54(5):987-89.

Keast A, Webb D. Mouth and body form relative to feeding ecology in the fish fauna of a small lake, lake Opinicon, Ontario. J Fish Res Board Can. 1966; 23(12):1845-74.

Krebs, CJ. Ecological methodology. Harper-Collins Publ, 1989.

Anderson MJ, Gorley RN, Clarke KR. PERMANOVA + for PRIMER: Guide to software and statistical methods. Plymouth: PRIMER-E; 2008.

Lacerda CHF, Barletta M, Dantas DV. Temporal patterns in the intertidal faunal community at the mouth of a tropical estuary. J Fish Biol. 2014; 85(5):1571-602.

Leibold MA. The niche concept revisited: mechanistic models and community context. Ecology. 1995; 76(5):1371-82.

Linden PVD, Marchini A, Smith CJ, Dolbeth M, Simone LRL, Marques JC, Molozzi J, Medeiros CR, Patricio J. Functional changes in polychaete and mollusc communities within two tropical estuaries. Estuar Coast Shelf Sci. 2017; 187:62-73.

Logothetis EA, Horn MH, Dickson KA. Gut morphology and function in Atherinops affinis (Teleostei: Atherinopsidae), a stomachless omnivore feeding on macroalgae. J Fish Biol. 2001; 59:1298-312.

MacArthur RH, Pianka ER. On optimal use of a patch environment. Am Nat. 1966; 100(916):603-09.

Moura GC, Barbosa JEL, Patrício J, Nery JF, Gonçalves AMM. Seasonal and spatial shifts in copepod diets within tropical estuaries measured by fatty acid profiles. Ecol Indic. 2016; 69:284-94.

Mourão JS, Nordi N. Etnoecologia de pescadores artesanais do estuário do rio Mamanguape, Paraíba, Brasil. Bol Inst Pesca. 2003; 29(1):9-17.

Neves ML, Pereira HH, Costa MR, Araujo FG. Uso do manguezal de Guaratuba, baia de Sepetiba, Rio de Janeiro, pelo peixe-rei Atherinella brasiliensis (Quoy and Gaimard) (Atheriniformes, Atherinopsidae). Rev Bras Zool. 2006; 23(2):421-28.

Nobrega-Silva C, Patrício J, Marques JC, Olimpio MS, Farias JNB, Molozzi J. Is polychaete family-level sufficient to assess impact on tropical estuarine gradients? Acta Oecol. 2016; 77:50-58.

Paiva Filho AM, Giannini R. Contribuição ao conhecimento da biologia do peixe-rei, Xenomelaniris brasiliensis (Quoy \& Gaimard, 1824) (Atherinidae), no complexo baía-estuário de Santos e São Vicente, Brasil. Bol Inst Pesca. 1990; 38(1):1-9.

Paiva MP, Scheffer AC. Maturidade e reprodução do peixe-rei Odontesthes bonariensis (Valenciennes), na bacia do rio Jacuí (Brasil). Ciência e Cultura. 1982; 34(12):1649-53.

Pessanha ALM, Araújo FG. Recrutamento do peixe-rei, Atherinella brasiliensis (Quoy \& Gaimard) (Atheriniformes, Atherinopsidae), na margem continental da baía de Sepetiba, Rio de Janeiro, Brasil. Rev Bras Zool. 2001; 18(4):1265-74.

Pessanha ALM, Araújo FG, Oliveira REMCC, Silva AF, Sales NS. Ecomorphology and resource use by dominant species of tropical estuarine juvenile fishes. Neotrop Ichthyol. 2015; 13(2):401-12.

Pinkas L, Oliphant MS, Iverson ILK. Fish Bulletin 152. Food habits of albacore, bluefin tuna and bonito in Californian Waters.UC San Diego: Library - Scripps Collection; 1970.

Platell ME, Potter IC. Partitioning of food resources amongst 18 abundant benthic carnivorous fish species in marine waters on the lower west coast of Australia. J Exp Mar Biol Ecol. 2001; 261(1):31-54.
Ringuelet RA. Ecología alimentícia del pejerrey Odontesthes bonariensis com notas limnologicas sobre la laguna Chascomús. Rev Mus la Plata, Sec Zool. 1942; 2(17):427-61.

Rocha AAF, Silva-Falcão EC, Severi W. Alimentação das fases iniciais do peixe-rei Atherinella brasiliensis (Atherinopsidae) no estuário do rio Jaguaribe, Itamaracá, PE. Rev Bras Ciênc Agrár. 2008; 3(4):365-70.

Rodrigues FL, Bemvenuti MA. Hábito alimentar e osteologia da boca do peixe-rei, Odontesthes humensis de Buen (Atheriniformes, Atherinopsidae) na lagoa Mirim, Rio Grande do Sul, Brasil. Rev Bras Zool. 2001; 18(3):793-802.

Ross LG, Martinez-Palacios CA, Valdez MCA, Beveridge MCM, Sanchez MCC. Determination of feeding mode in fishes: the importance of using structural and functional feeding studies in conjunction with gut analysis in a selective zooplanktivore Chirostoma estor estor Jordan 1880. J Fish Biol. 2006; 68(6):1782-94.

Ross ST. Resource partitioning in fish assemblages: a review of field studies. Copeia. 1986; 1986(2):352-88.

Santos ACA, Castullucci FRC, Nepomuceno CF, Santos EP, Sena MP. Distribuição e recrutamento do peixe-rei Atherinella brasiliensis (Osteichthyes, Atherinidae) na margem continental oeste de baía de Todos os Santos, Bahia, Brasil. Acta Biol Leopold. 1999; 21(1):107-18.

Schaefer KM. An evaluation of geographic and annual variation in morfometric characters and gill-raker counts of yellowfin tuna, Thunnus albacares, from the Pacific ocean. IATTC Bull. 1992; 20(3):133-63.

Schafer LN, Platell ME, Valesini FJ, Potter IC. Comparisons between the influence of habitat type, season and body size on the dietary compositions of fish species in nearshore marine waters. J Exp Mar Biol Ecol. 2002; 278(1):67-92.

Scholosser IJ. The role of predation in age-and size- related habitat use by stream fishes. Ecology. 1987; 68(3):651-59.

Sheaves M, Baker R, Nagelkerken I, Connolly RM. True value of estuarine and coastal nurseries for fish: Incorporating complexity and dynamics. Estuar Coast. 2014; 38(2):401-14.

Souza-Bastos LR, Freire CA. Osmoregulation of the resident estuarine fish Atherinella brasiliensis was still affected by an oil spill (Vicuña tanker, Paranaguá Bay, Brazil), 7 months after the accident. Sci Total Environ. 2011; 409(7):1229-34.

Unger PA, Lewis Jr WM. Selective predation with respect to body size in a population of the fish Xenomelaniris venezuelae (Atherinidae). Ecology. 1983; 64(5):1136-44.

Unger PA, Lewis Jr WM. Population ecology of a pelagic fish, Xenomelaniris venezuelae (Atherinidae), in lake Valencia, Venezuela. Ecology. 1991; 72(2):440-56.

Ward AJW, Webster MM, Hart PJB. Intraspecific food competition in fishes. Fish Fish. 2006; 7:231-61.

Watson DJ, Balon EK. Ecomorphological analysis of fish taxocenes in rainforest streams of northern Borneo. J Fish Biol. 1984; 25:371-83.

Whitfield AK. The role of zooplankton in the feeding ecology of fish fry from some Southern African estuaries. S Afr J Zool. 1985; 20(3):166-71. 